\title{
sciendo
}

CIVIL AND ENVIRONMENTAL ENGINEERING REPORTS

E-ISSN 2450-8594

CEER 2021; 31 (2): 0105-0116

DOI: $10.2478 /$ ceer-2021-0022

Case study

\section{A METHOD TO REDUCE AIR HEATING COSTS IN WINTER PERIOD IN THE KRÓLOWA LUIZA MINING MUSEUM IN ZABRZE - CASE STUDY}

\author{
Krzysztof SŁOTA ${ }^{1 *}$, Zbigniew SŁOTA ${ }^{1}$ \\ Faculty of Mining, Safety Engineering and Industrial Automation, Silesian University of \\ Technology, Gliwice
}

\begin{abstract}
The Królowa Luiza Mining Museum is one of the touristic objects of the Coal Mining Museum in Zabrze. In the study in concern, an assessment of ventilation of the facility was conducted. Following the assessment of the ventilation, the operating parameters of the fans were changed, inlets were sealed and a system of air ducts was designed and constructed. The ducts reintroduce the heated air from the facility to workings. The conducted activities aimed to decrease the amount of air has increased the temperature in the entire object by from 3 to $10^{\circ} \mathrm{C}$, which translated into a profit of approximately 200 Euro a day. Before changing the heating system it was impossible to achieve a positive temperature in the entire object at an external temperature of $-10^{\circ} \mathrm{C}$. It was necessary to close the Museum for tourists. Trials conducted for the external temperature from -2 to $-6^{\circ} \mathrm{C}$ have exhibited that it will be possible to achieve positive temperatures in the entire facility even in case of very low external temperatures. The costs borne for the change of the heating system may be estimated at a level of 25000 Euro. The return of the investment should occur in the first Winter period.
\end{abstract}

Keywords: ventilation, tourist traffic, reduce air heating costs, recuperation

\footnotetext{
*Corresponding author: Faculty of Mining, Safety Engineering and Industrial Automation, Silesian University of Technology, Gliwice, e-mail: Krzysztof.slota@polsl.pl
} 


\section{INTRODUCTION}

The „Królowa Luiza” Mining Museum is an underground facility prepared and made accessible for touristic traffic. It constitutes one of the objects of the Coal Mining Museum in Zabrze. The workings of the Museum are located at a low depth. Ventilation of the Museum is conducted by means of two WGL/KGC-6A fans located - one in the ,old" part - with a power of $18,5 \mathrm{~kW}$ and the second in the ,new” part, with a power of $22 \mathrm{~kW}$. In the entire facility, three used air outlets may be distinguished (two connected with fans) as well as seven ,skylights" and two inlets used for providing fresh air. Due to the fact that the air may not be heated by the rock mass, it is necessary to heat the air during the Winter period. To ensure proper climatic conditions, both for the visitors and the machines and devices located in the Museum, air heaters were installed. The power of the heaters with the power of $90 \mathrm{~kW}$ is not always sufficient, especially in case of such a complicated ventilation network and with that many air inlets and outlets, to ensure a positive temperature of air in the entire object. An attempt was thus made to change the ventilation method by changing the amount of air (change in the settings of one of the fans, limiting the amount of air inflowing through skylights) as well as by reintroduction of heated air flowing out of the Museum the performance of the so-called partial recirculation of air. Recylculation consisted in reintroducing heated air from the outlet holes to the inlet holes by connecting them with lute pipes. The amount of reintroduced air was regulated by valves.

\section{MATERIALS AND METHODS}

The Królowa Luiza Mining Museum is an underground facility. The flow of air through the workings is achieved by means of two air duct fan stations with an efficiency of $6 \mathrm{~m}^{3} / \mathrm{s}$ each.

In the Autumn-Winter-Spring period, air heaters with a maximum power of 90 $\mathrm{kW}$ are an additional element introduced into the ventilation system. At low external temperatures it is not always possible to ensure positive temperatures in the entire underground facility, For it to be possible to make the Museum accessible to tourists in such periods, a concept of heating the object using air flowing out through the fans and its partial re-introduction was developed.

The concept and the design were primarily aimed at:

- the improvement of climatic conditions in Winter period, especially by the increase of air temperature,

- reduction of costs related to the amount of flowing air - by changing the fan operational parameters. 
- limitation of power costs related to heating the air flowing through the workings of the Museum.

- eliminating the possibility of freezing firefighting pipelines,

- heating the entire facility in such a manner so as a positive temperature was present in all workings and their vicinity, which will limit the degradation and erosion of the rock mass (eliminating the freezing of the rock mass).

The assumed goals have forced the mode of conduct and performance of design, preparatory, structural, analytical and measurement works. Among other things, the following works were conducted:

- ventilation diagrams were analyzed in view of the number of air inlets and outlets,

- measurements of the ventilation network were conducted along air balance calculations, losses were determined (the ventilation diagram of the Królowa Luiza Mining Museum after changing the ventilation in Winter has been presented in Fig. 1.),

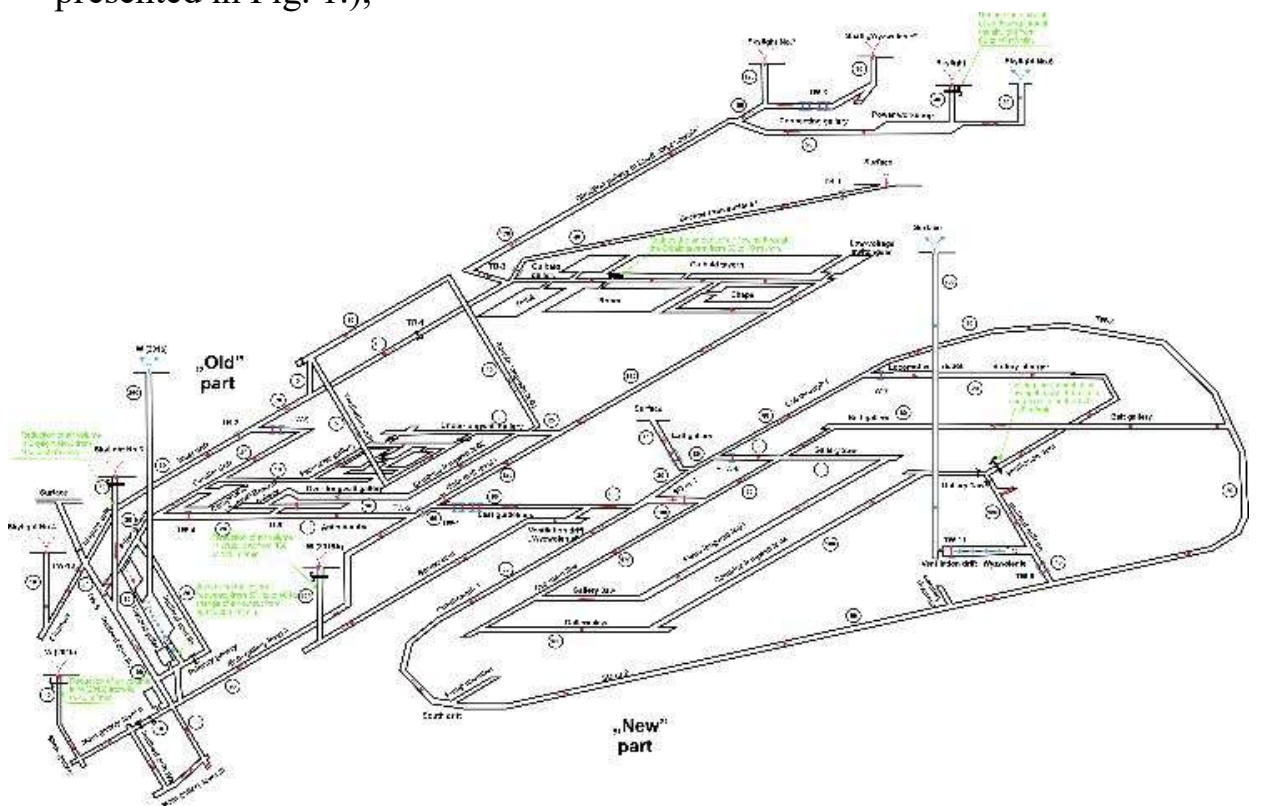

Fig. 1. The ventilation diagrams of the Królowa Luiza Mining Museum after changing the ventilation in Winter

- amount of air flowing in through skylight in the electric al workshop was limited, along the intake of water migrating from the roof and installation of drains along the dip-heading from the surface (roof dewatering), 
- shutters were installed in skylight No. 7, which caused a higher contact of air flowing in through this skylight with the heater that is installed in that location,

- dams TB-1 and TB-3 were unsealed by dismantling one of the lower aprons in the TB-3 dam and by removing the window pane in the window of the TB-1 dam, which resulted in the inflow of warm air to the Museum from the cash desk building,

- amount of air flowing through Gibald tavern was decreased,

- the inlet to the opening W(2016) was sealed and fitted with a regulation window allowing for the regulation of air flowing through the level III (Fig. 2.),

- regulation window was installed in the skylight No. 3, allowing to control the amount of air flowing through the IIIz inclined drift (Fig. 3.)

- regulation window was installed in the opening $\mathrm{W}(2015 \mathrm{a})$, regulating the amount of air in the mining area boundary drift (Fig. 4.),

- a regulating window (Fig. 5., Fig. 6.) was installed in the opening W(2015), allowing for the regulation of amount of fresh air inflowing to the air duct,

- a pre-insulated air duct was installed at the surface for connecting the opening $\mathrm{W}(2015)$ with the opening W(2016), which allowed for supplying heated air by means of partial recirculation (Fig. 7.),

- the openings W(2015) and W(2015a) were connected by means of a preinsulated air duct, which allowed for supplying heated air to the boundary drift and to the „new” part (Fig. 8., Fig. 9.),

- a regulation window was installed in the ventilating duct, which allowed to decrease the amount of air in the battery charging station,

- possibilities of changing the fan operational parameters were analyzed, current was decreased in case of the fan in the „old" part by decreasing the inverter frequency from $50 \mathrm{~Hz}$ to $40 \mathrm{~Hz}$. 

KRÓLOWA LUIZA MINING MUSEUM IN ZABRZE - CASE STUDY

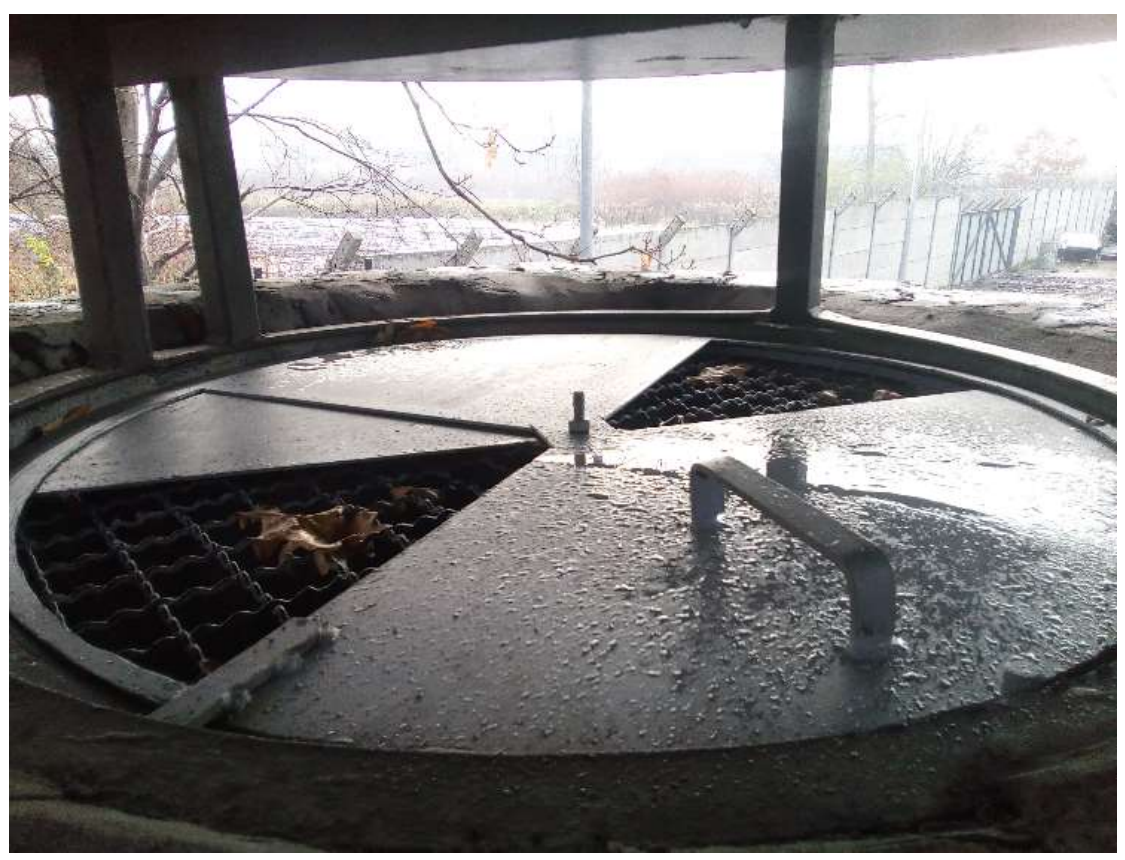

Fig. 2. The opening W(2016) - the regulation window (author's photo)

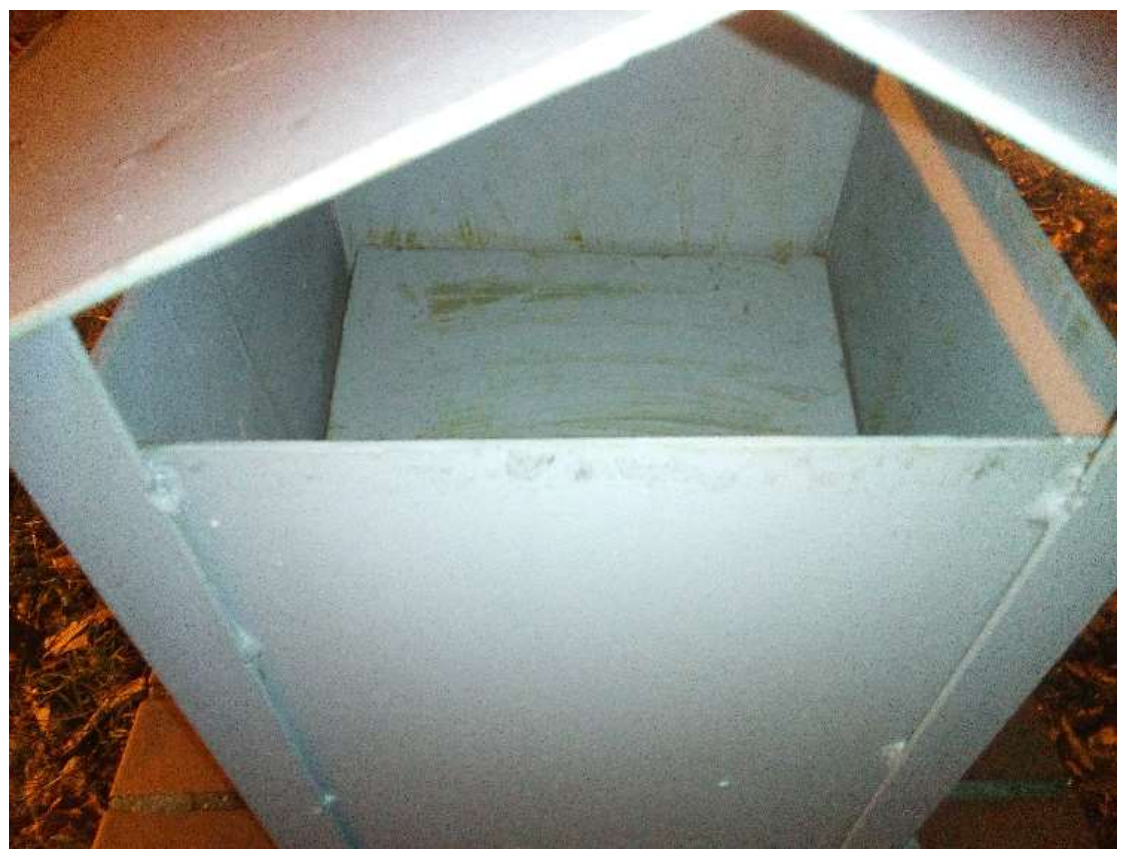

Fig. 3. The skylight No. 3 - the regulation window (author's photo) 


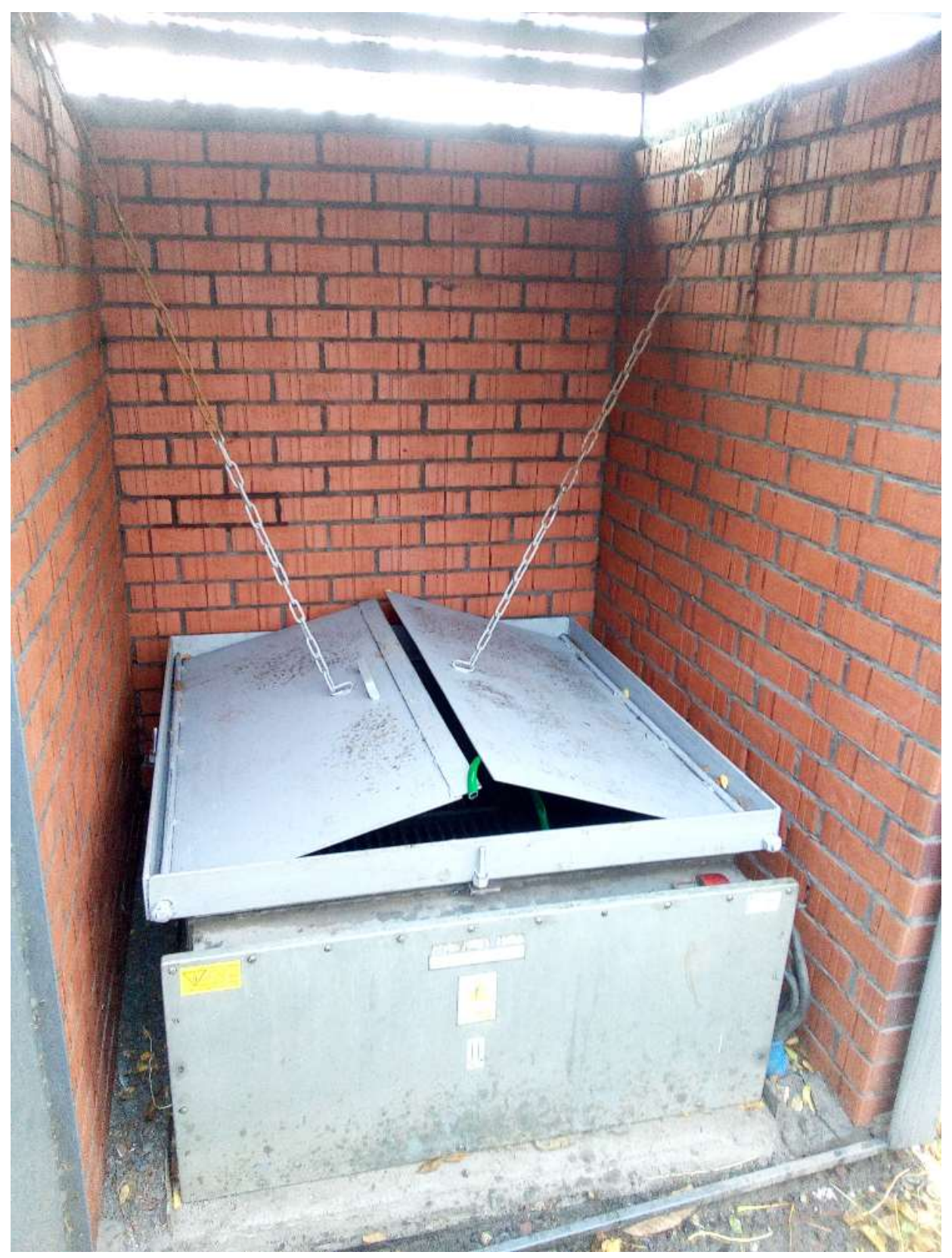

Fig. 4. The opening W(2015a) - the regulation window (author's photo) 

KRÓLOWA LUIZA MINING MUSEUM IN ZABRZE - CASE STUDY

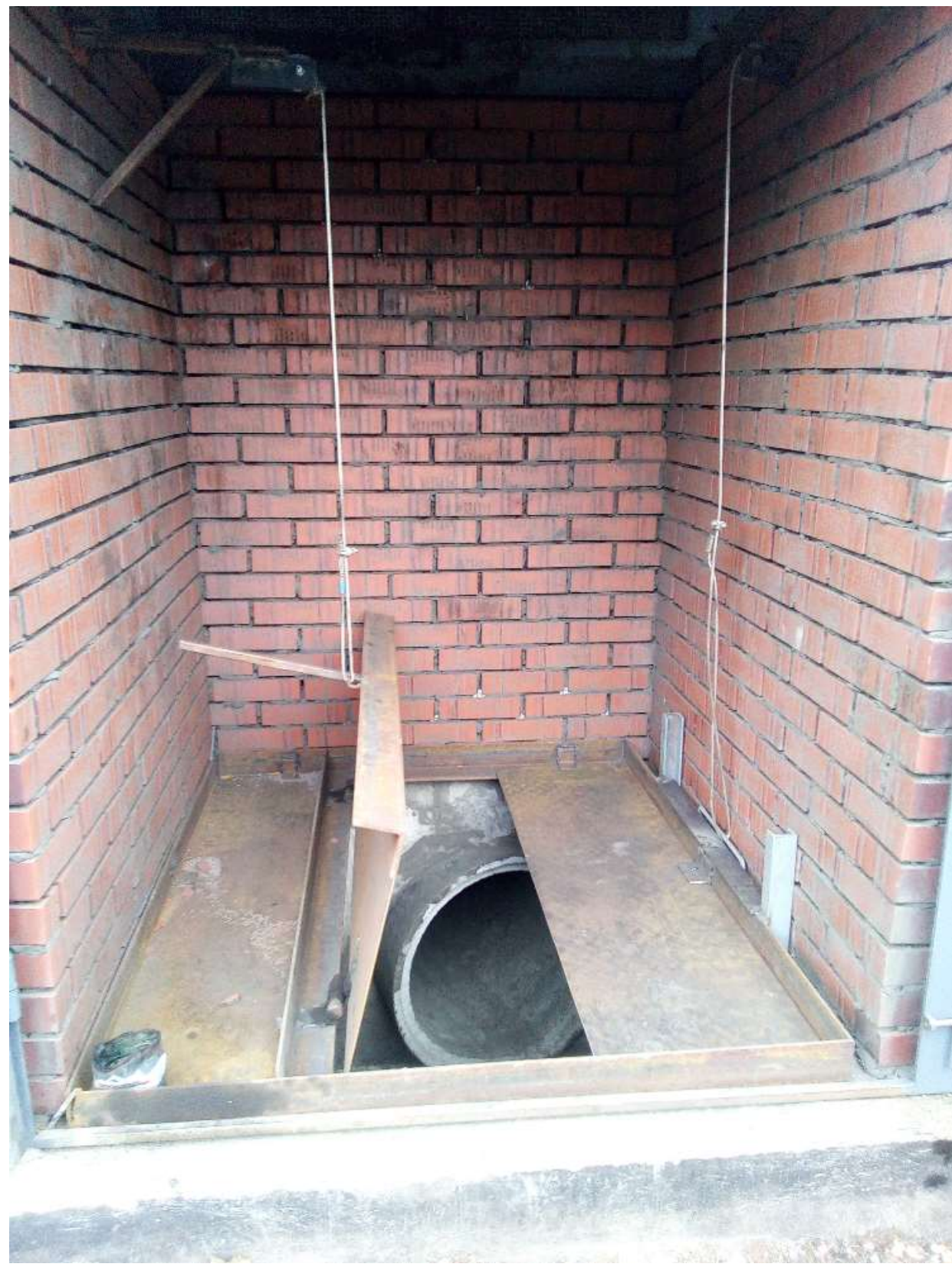

Fig. 5. The opening W(2015) - the regulation window - view inside (author's photo) 


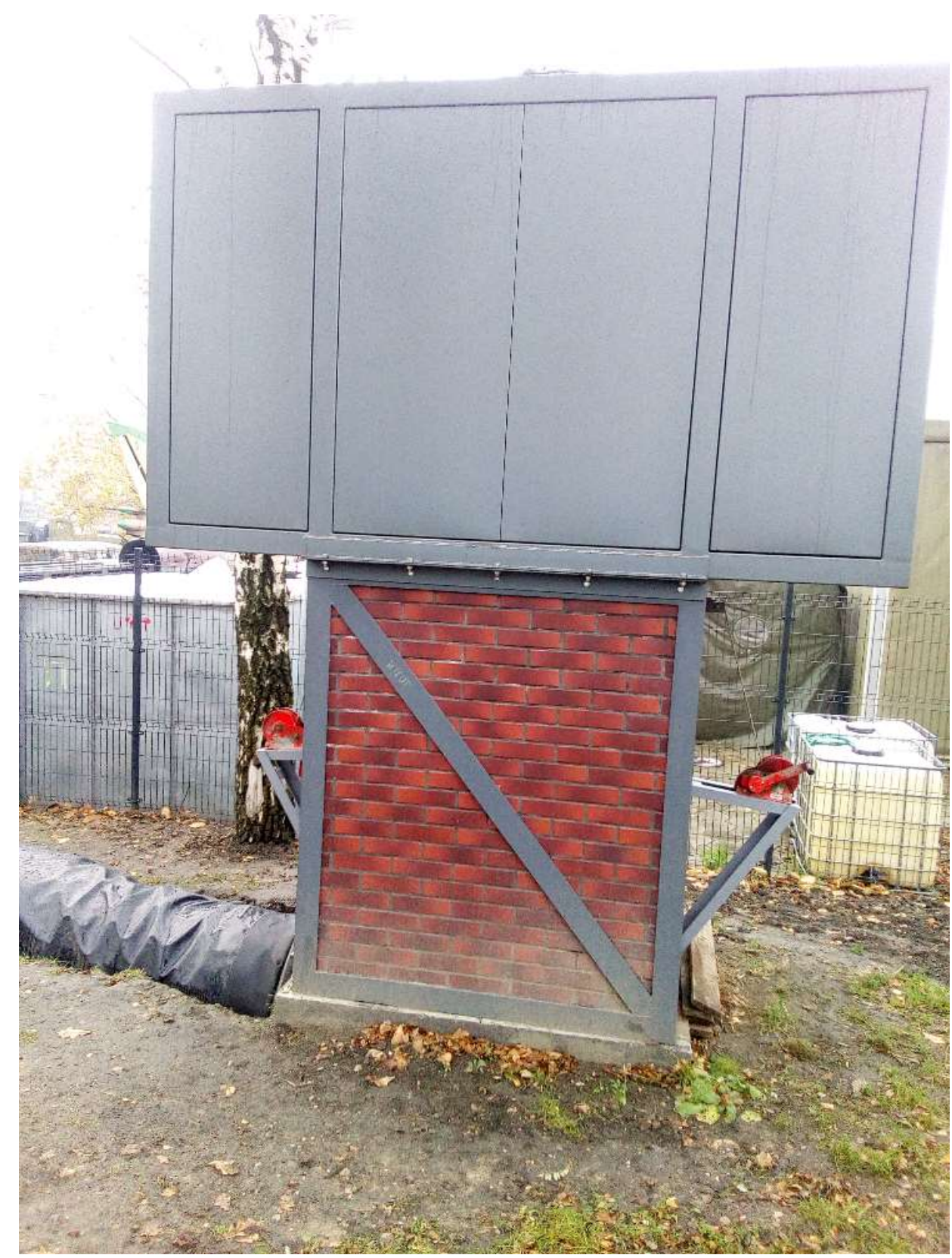

Fig. 6. The opening W(2015) - the regulation window - outside view (author's photo) 


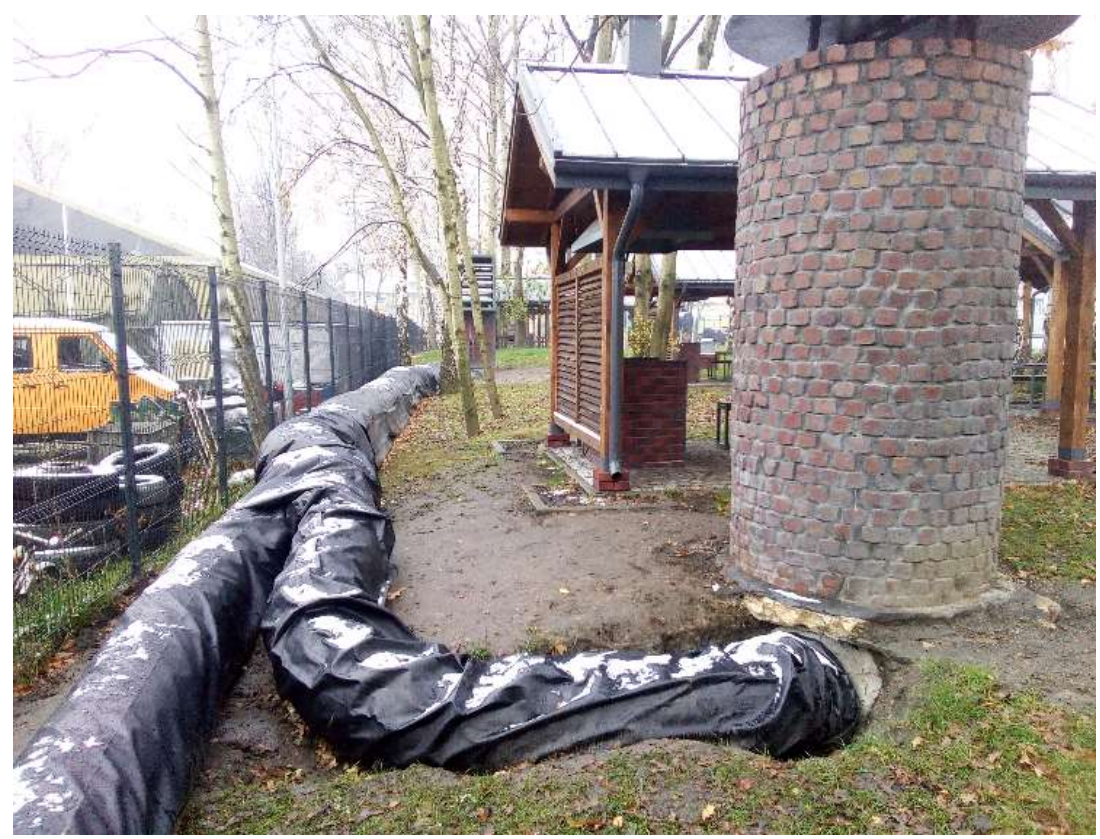

Fig. 7. The air duct installed at the surface for connecting the opening W(2015) with the opening W(2016) - the recuperation (author's photo)

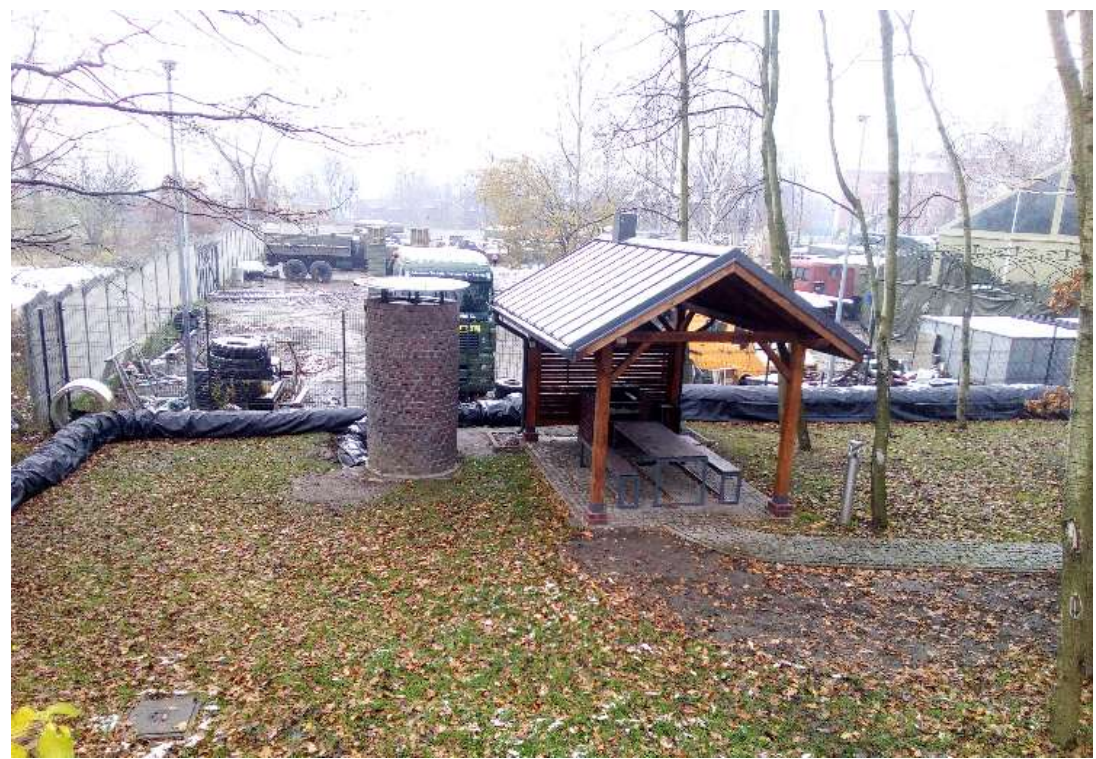

Fig. 8. The air duct installed at the surface for connecting the opening W(2015) with the opening $\mathrm{W}(2016)$ and $\mathrm{W}(2015 \mathrm{a})$ - the recuperation - the opening $\mathrm{W}(2016)$ (author's photo) 


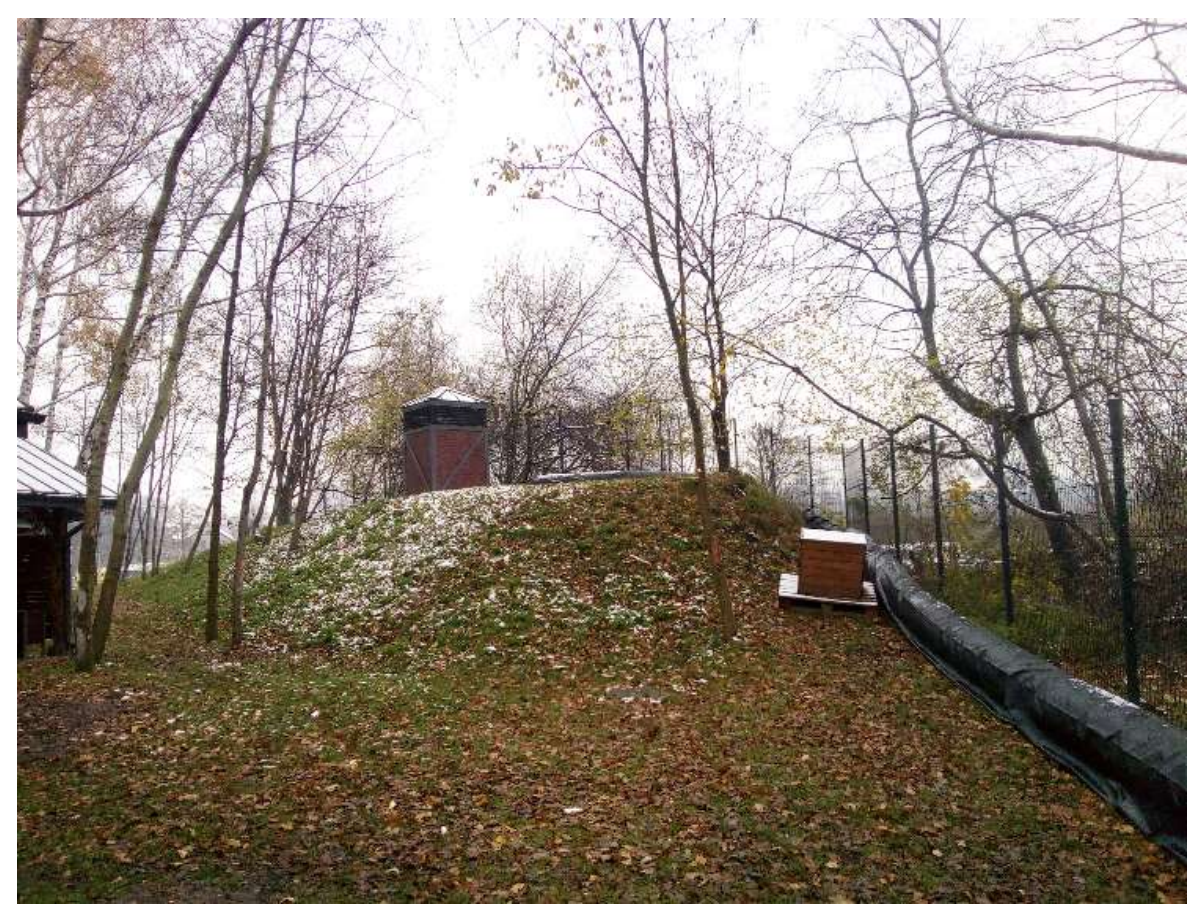

Fig. 9. The air duct installed at the surface for the recuperation - the opening W(2015a) (author's photo)

\section{RESULTS AND CONCLUSIONS}

In line with the assumed goals, the works allowed for:

- decreasing the amount of air flowing through the fan installed in the „old" part by approximately $100 \mathrm{~m}^{3} / \mathrm{min}$ by changing the frequency of current of the inverter, which significantly limited the costs related to ventilation (by over $25 \%)$

- the amount of heat was determined on the basis of mining regulations. According to the plant manager's recommendations, it was necessary to ensure the correct chemical composition of the air. The minimum oxygen content in the air was set at $19 \%$ and the maximum carbon dioxide content at $1 \%$,

- limiting the inflow of fresh cold air to the Museum and the partial recuperation achieved by connecting the outlet opening W(2015) with skylights has largely decreased the costs related to heating the air in the entire facility, by a mean amount of 200 Euro a day; the energy costs were estimated based on standard energy consumption meters installed at the fans, the heater and the cashier building, 
- conducting works in the TB-1 and TB-3 dams allowed for the introduction of heated air from the building to the museum and two kinds of savings in terms of the heating costs - first - the air in the workings of the Museum and the second being the fact that the heated air was not delivered outside the building and lost,

- regulating the air in the skylight providing air to the level III, allowed for its minimization and control as well as the maintenance of safe carbon dioxide concentrations (level III is connected to the old goafs, from where carbon dioxide is emitted into the workings at high pressure drops; for this purpose, a carbon dioxide sensor connected to a pressure sensor has been installed; when a danger is detected, the amount of air in the area is automatically increased the operation of fans is changed.),

- decreasing the amount of air flowing through the battery charging station allowed for directing the air to remaining regions,

- mean increase of temperature in the entire facility varied from 3 to $10^{\circ} \mathrm{C}$ (Table 1.).

Table 1. Temperature measurement results without and including recuperation

\begin{tabular}{|c|c|c|c|}
\hline $\begin{array}{l}\text { Outside } \\
\text { temperature }\end{array}$ & $\begin{array}{c}\text { Temperature measurement } \\
\text { point }\end{array}$ & $\begin{array}{l}\text { Air temperature } \\
\text { without } \\
\text { recuperation }\end{array}$ & $\begin{array}{l}\text { Air temperature } \\
\text { within the range } \\
\text { of recuperation }\end{array}$ \\
\hline${ }^{\circ} \mathrm{C}$ & & ${ }^{\circ} \mathrm{C}$ & ${ }^{\circ} \mathrm{C}$ \\
\hline \multirow{4}{*}{$\begin{array}{c}10 \\
\text { (without air } \\
\text { heater } \\
\text { operation) }\end{array}$} & A - Guibald tavern & 14 & 15 \\
\hline & $\mathrm{B}$ - Combine longwall N-02 & 16 & 18 \\
\hline & C - Main gallery level II & 12 & 15 \\
\hline & D - Plane longwall N-03 & 16 & 18 \\
\hline \multirow{4}{*}{5} & A - Guibald tavern & 15 & 16 \\
\hline & $\mathrm{B}$ - Combine longwall N-02 & 17 & 19 \\
\hline & C - Main gallery level II & 7 & 14 \\
\hline & D - Plane longwall N-03 & 9 & 15 \\
\hline \multirow{4}{*}{0} & A - Guibald tavern & 11 & 14 \\
\hline & $\mathrm{B}-$ Combine longwall N-02 & 13 & 15 \\
\hline & $\mathrm{C}$ - Main gallery level II & 2 & 10 \\
\hline & D - Plane longwall N-03 & 5 & 11 \\
\hline \multirow{4}{*}{-5} & A - Guibald tavern & 7 & 11 \\
\hline & B - Combine longwall N-02 & 9 & 12 \\
\hline & $\mathrm{C}$ - Main gallery level II & -3 & 4 \\
\hline & D - Plane longwall N-03 & 2 & 9 \\
\hline \multirow{4}{*}{-10} & A - Guibald tavern & 3 & 7 \\
\hline & $\mathrm{B}-$ Combine longwall N-02 & 5 & 8 \\
\hline & $\mathrm{C}$ - Main gallery level II & -7 & 0 \\
\hline & D - Plane longwall N-03 & -2 & 5 \\
\hline
\end{tabular}




\section{CONCLUSION}

The works conducted to that moment allowed for a significant decrease in costs related to the ventilation and heating system in the Museum. The return of the costs borne in the amount of 25000 euro, should occur after the first Winter period. Further works on the safety of the ventilation network and reduction of costs as well as ensuring proper climatic conditions require further investments. Among other things, these are related with:

- the installation of inverter in the second fan - cost of approx. 2500 Euro, which shall allow for fluent and safe regulation of operational parameters (regulation using plates is not economic),

- the exchange of air heater to a more efficient one - with different structure and ensuring a better heat Exchange with the flowing air.

\section{ADDITIONAL INFORMATION}

Sources of finance: Faculty of Mining, Safety Engineering and Industrial Automation, Silesian University of Technology, Gliwice, 06/050/BK-50/0098 and Coal Mining Museum in Zabrze.

\section{REFERENCES}

1. Słota, K 2017. Conceptual works regarding the reduction of costs of ventilation and heating in the Królowa Luiza Mining Museum in Zabrze. Materials of the Coal Mining Museum in Zabrze, (unpublished).

Editor received the manuscript: 29.11.2020 